\title{
Remediation of cadmium contaminated vertisol mediated by Prosopis charcoal and coir pith
}

\section{Palaninaicker Senthilkumar a, Duraisamy Prabha ${ }^{b, *}$ Subpiramaniyan Sivakumar c, Chandra Venkatasamy Subbhuraam b}

a Periyar University, Department of Environmental Sciences, Salem, India

b Bharathiar University, Department of Environmental Sciences, Coimbatore, India

c Pusan National University, College of Natural Resource and Life Science, Department of Bioenvironmental Energy, Miryang, South Korea

\begin{abstract}
Metal contamination of soil due to industrial and agricultural activities is increasingly becoming a global problem, thereby affecting animal and human life, thus rendering soil unsuitable for agricultural purposes. Remediation of cadmium (Cd) contaminated soil (Vertisol) using agricultural by products as source of organic amendments, Coir pith- a by-product of the coir industry and Prosopis charcoal- prepared by burning Prosopis plant wood (Prosopis juliflora L.) was investigated. The alleviation potential of Prosopis charcoal and Coir pith on the negative effects of Cd in soil was evaluated in pot culture experiments with Vigna radiata as the test plant, a Cd accumulator. Cadmium addition to soil resulted in accumulation of $\mathrm{Cd}$ in all plant parts of $V$. radiata predominantly in roots. The influence of $\mathrm{Cd}$ in the presence and absence of organic amendments on the various biological and chemical parameters of the soil, on the levels of Cd accumulation and on the growth attributes of $V$. radiata has been assessed. Among the organic amendments, Prosopis charcoal was found to be more effective in reducing the bioavailable levels of $\mathrm{Cd}$ in the soil artificially spiked with Cd in graded concentrations of $0,5,10,20,40,60$, 80 and $100 \mu \mathrm{g} \mathrm{g}^{-1}$ and its accumulation in V. radiata, thus resulting in an increase in the root, leaf and stem biomass. Coir pith, however, was effective in increasing the total mycorrhizal colonization of roots and second in reducing Cd levels in plants. Therefore, Prosopis charcoal was considered best for stabilization of $\mathrm{Cd}$ in soil.
\end{abstract}

Accepted : 20.11.2014

Keywords: Cadmium, organic amendments, Prosopis charcoal, Coir pith, Vigna radiata, accumulation

(C) 2014 Federation of Eurasian Soil Science Societies. All rights reserved

\section{Introduction}

Soil contamination with heavy metals are increasing on a global scale due to waste emissions from industrial production, mining activities, waste (i.e, biosolids and manure) application, wastewater irrigation, and inadequate management of pesticides and chemicals in agricultural production (Bolan et al., 2004; Mench et al., 2010). Soil heavy metal pollution poses a risk to the environment and to human health (Roy and McDonald, 2014) due to biomagnifications. Soil pollution with heavy metal has a malicious effect on soil microbial properties (Yang et al., 2012) and on the taxonomic and functional diversity of soils (Vacca et al., 2012). While some of these elements are essential for living organisms certain others are non-essential.

\footnotetext{
${ }^{*}$ Corresponding author.

Bharathiar University, Department of Environmental Sciences, Coimbatore 641046, India

Tel.: +929789776549

ISSN: $2147-4249$
}

E-mail address: prabhasidd@gmail.com 
Among them Cd, at present is receiving the largest attention as the most important metal in the soil pollution problem because of the very narrow gap existing between the level of its consumption through many crops and the level at which it causes significant human health effect. All commercial Cd is a by-product of Zinc production, and there are no ores mined and processed exclusively for $\mathrm{Cd}$. It occurs widely in nature in small amounts. Many anthropogenic activities such as mining and metal processing operations, burning of fossil fuels, production and use of phosphate fertilizers, heating systems, industrial waste disposals, sewage sludge disposals on land, waste incinerators, urban traffic, cement factories, electroplating operations, pigment production and cadmium-nickel battery production units (Mhatre and Pankhurst; 1997; Sanita di Toppi and Gabbrielli, 1999) are the sources of Cd to soils.

At present, remediation methods for heavy metal contaminated soil include physical, biological and chemical treatments. Among them, chemical remediation typically employs soil amendments which can reduce their bioavailability through a variety of reactions. The technology relies on choosing an economic and effective amendment (Mercier and Detellier, 1995). Many scientists have studied the adsorption of heavy metals on clay minerals including zeolite, sepiolite, attapulgus, illite, montmorillonite and other natural clay minerals or modified forms, and have found that they have great potential to remove heavy metals from water (Liu and Gonzalez, 1999; Liu 2007; Missana et al., 2008; Bailey et al., 1999; Gworek, 1992). These clay minerals are low cost materials and offer an attractive and inexpensive remediation option. They are abundant and cheap, with negatively charged layered aluminosilicates that make them good cationic adsorbents because of their relatively large surface areas (Wu et al., 2009). In recent years, researchers have used clay minerals in the remediation of heavy metal contaminated soil and achieved positive results (Haidouti, 1997; Zorpas et al., 2000; Nissen et al.,2000; Garćla et al., 1999).

Organic amendments have also been used in the remediation of heavy metal contaminated soils (Herwijnen et al., 2007). Application of organic matter in forms such as cattle manure, pig manure, chicken manure, peat and crop straw are inexpensive, highly available and feasible in the restoration of heavy metal contaminated soils. It was shown by Sauvé et al. (2003) that the adsorption ability of heavy metals on soil organic matter is 30 times that of the clay minerals, so soils with high organic matter content had a higher adsorption capacity and could effectively reduce the mobility of heavy metals. The stability of the complex will influence the bioavailability and extraction of heavy metals by plants. In addition, the organic materials can affect the acidity and redox properties of the soil (Walker et al., 2003; 2004). Although in-situ remediation with amendments for heavy metal contaminated soils is widely studied, the impact of organic matter on the element retention is case specific and generalizations are difficult to make (Kumpiene et al., 2008).

In the present investigation, a pot experiment was conducted to screen for environmentally friendly and low cost soil amendments which will be capable of remediating $\mathrm{Cd}$ contaminated soils. Organic amendments are known immobilizers of metals in the soil environment. However, their efficiency has to be assessed using a plant species, specifically an accumulator or hyperaccumulator. Hence, in this study, the influence of $\mathrm{Cd}$ in the presence and absence of organic amendments on the various chemical and biological parameters of the soil, on the levels of Cd accumulation and on the growth attributes of V.radiata has been assessed.

\section{Material and Methods}

Soil (alfisol) used in this study was sampled from the agricultural land in, Coimbatore, India. It is characterized by clay loam in texture, bulk density $1.3 \mathrm{~g} \mathrm{cc}^{-1}, \mathrm{pH} 6.9$ (1:2.5 soil water suspension), electrical conductivity $0.38 \mathrm{mS} \mathrm{cm}^{-1}$ and organic carbon (OC) $0.68 \%$. The soil was air-dried under shade and sieved through $1 \mathrm{~mm}$ sieve for analysis of various soil properties. Soil-available nutrient and metal concentrations in micrograms per gram were $\mathrm{Cu} 2.98$, zinc 4.12, iron 4.84, manganese 92.78, cadmium 0.98, nitrogen (N) $1.30 \%$, phosphorus $0.018 \%$, potassium $(\mathrm{K}) 0.010, \mathrm{R}_{2} \mathrm{O}_{3} 8.76 \%$. Coir waste and Prosopis charcoal powder were used as soil amendments. Coir pith, a by product of the coir industry, was obtained from agricultural lands and Prosopis charcoal, prepared by burning the Prosopis plant wood (Prosopis juliflora L.) was obtained from commercial sources. The materials were dried, sieved through a $2 \mathrm{~mm}$ sieve to obtain uniform particle size and used for this study. Physico-chemical characteristics of raw Coir pith and Prosopis charcoal are given in Table 1.

\section{Pot culture experiments}

Ten Kilogram of soil mixed with varying concentrations of organic amendments $(50,125,250 \mathrm{~g} / 10 \mathrm{~kg}$ of soils) were filled in earthen pots $(27 \mathrm{~cm}$ height by $29 \mathrm{~cm}$ diameter) lined with polythene sheet. The soils were spiked with graded concentration $(0,5,10,20,40,60,80$ and $100 \mu \mathrm{g} \mathrm{g}-1)$ of cadmium chloride $\left(\mathrm{CdCl}_{2} \cdot \mathrm{H}_{2} \mathrm{O}\right)$ (AR grade) solution and mixed thoroughly, and fertilized with a standard basal fertilizer $(0.313 \mathrm{~g}$ of $\mathrm{N}$ and 
$0.782 \mathrm{~g}$ of P to $10 \mathrm{~kg}$ soil). All treatments were performed in triplicate. The soils were given two wetting and drying cycles over a 2 weeks period to ensure better contact between the soil and the heavy metal. One day prior to planting, the soil treatments were remoistened with water and the seeds of green gram, Vigna radiata were planted at a rate of 6 seeds per pot at a depth of $0.5 \mathrm{~cm}$. The seedlings were thinned to three per pot 15 days after growth. The pots were arranged in complete randomized design (CRD) and maintained under green house conditions.

Table 1. Composition of organic amendments

\begin{tabular}{lll}
\hline Composition & Raw Coir Pith & Prosopis charcoal \\
\hline Cadmium $(\mu \mathrm{g} / \mathrm{g})$ & 0.06 & 0.18 \\
Nitrogen (\%) & 0.26 & 0.46 \\
Phosphorous (\%) & 0.01 & 0.02 \\
Potassium (\%) & 0.78 & 2.85 \\
Organic carbon (\%) & 23.4 & 73.8 \\
Lignin (\%) & 30 & - \\
Cellulose (\%) & 26 & - \\
Calcium (\%) & 0.40 & 1.85 \\
Magnesium (\%) & 0.36 & 0.52 \\
Iron (ppm) & 0.07 & 2.30 \\
Manganese (ppm) & 12.50 & 42.80 \\
Zinc (ppm) & 7.50 & 26.50 \\
Copper (ppm) & 3.10 & 6.92 \\
C:N ratio & $112: 1$ & $160: 1$ \\
pH & 6.36 & 9.82 \\
EC (millimhos/cm) & $0.4-1$ & 3.81 \\
\hline
\end{tabular}

\section{Plant and soil analysis}

The plants were harvested 65 days after sowing. Roots were carefully removed from the pots, shaken free of soil in a manner so as to minimize the loss of nodules and washed with distilled water, air dried for $48 \mathrm{hrs,}$ and then dried in an oven at $60{ }^{\circ} \mathrm{C}$ for $48 \mathrm{hrs}$. The dried samples were ground and digested with $\mathrm{HNO}_{3}, \mathrm{H}_{2} \mathrm{SO}_{4}$ and $\mathrm{HClO}_{4}$ at the ratio of 9:2:1 (Piper, 1966) prior to estimation of their mineral and Cd content. The sub samples of roots were taken for the measurement of mycorrhizal colonization. Arbuscular myccorhizal colonization was estimated employing the method of Muthukumar et al. (1996). Soil samples were air-dried and sieved $(2 \mathrm{~mm})$ before chemical analysis. The soil Cd were extracted in DTPA solution (Lindsay and Norvell, 1978). Soil and plant Cd was measured using Atomic Absorption Spectrophotometer (Pyeunicom SP9, Philips, UK). Bacterial population was measured employing standard method (Jha et al., 1992).

\section{Cadmium sorption}

Sorption of Cd by different amendments added soil, was performed by weighing $2 \mathrm{~g}$ soil in $100 \mathrm{ml}$ plastic bottles and equilibrated with $20 \mathrm{ml}$ of $0.01 \mathrm{M} \mathrm{Ca}\left(\mathrm{NO}_{3}\right)_{2}$ solution containing graded levels of $\mathrm{Cd}(5,10,20,40$, $60,80,100 \mu \mathrm{g} / \mathrm{g}$ as $\mathrm{CdCl}_{2}$ solution. The soil suspension was equilibrated for $24 \mathrm{~h}$ at $25 \pm 2$ on an environmental shaker. After equilibrium time (24hrs), the suspension was centrifuged and concentration of $\mathrm{Cd}$ in the supernatant was determined using AAS. Amount of $\mathrm{Cd}$ adsorbed was calculated by the difference between the amount of Cd added and that remaining in the solution (Adhikari and Singh, 2003).

\section{Statistical analysis}

The soil quality parameters and the growth parameters of green gram grown on soil with different organic amendments were subjected to analysis of variance and the means were separated using Duncans Multiple Range Test (DMRT) (Alder and Roessler, 1977). Percent values of mycorrhizal colonization were arcsine square root transformed and spore data were log transformed prior to statistical analysis. The results were expressed as mean \pm SD and the interrelations between parameters were assessed using correlation test.

\section{Results and Discussion}

\section{Cd sorption}

Sorption of $\mathrm{Cd}$ as measured by the percent removal of $\mathrm{Cd}$ from the soil solution increased with an increase in the concentration of amendments. Maximum sorption amount of $\mathrm{Cd}$ was highest in Prosopis charcoal compared to coirpith. The sorption data fitted well with the Freundlich model, 


\section{$\log \mathrm{qe}=\log \mathrm{K}_{\mathrm{f}}+1 / \mathrm{n} \log \mathrm{Ce}$}

Where, Ce is the equilibrium concentration of metal in solution $(\mathrm{mg} / \mathrm{L})$, qe is the amount of metal sorbed onto the soil and organic materials $(\mathrm{mg} / \mathrm{g})$, and $\mathrm{K}_{\mathrm{f}}$ and $1 / \mathrm{n}$ are Freundlich constants, which corroborates with the results of Kalmykova et al. (2008).

\section{Cadmium toxicity on soil}

Cadmium addition to soil increased the bioavailable $\mathrm{Cd}$ in the soil and thereby its accumulation in plant parts of Vigna radiata. The DTPA extract of Cd increased (80 to 3026\%) (Figure 1) with increasing soil amendment concentration of $\mathrm{Cd}\left(5\right.$ to $100 \mu \mathrm{g} \mathrm{g}^{-1}$ ). With increasing level of $\mathrm{Cd}$ in soil, $\mathrm{pH}$, the most important chemical factor governing the availability of a heavy metal in the soil (Li et al., 2011) also decreased (Table 2). Cadmium amendment also affected the bacterial population in the soil. The negative correlation that existed between the soil $\mathrm{Cd}$ and bacterial populations was an indication of combined stress of toxicity and undernourishment to which the bacterial population was subjected to, which resulted in a decrease in its population with an increase in the concentration of $\mathrm{Cd}$ in the soil. The bacterial population of control soil which was $26 \times 10^{3} \mathrm{CFU} / \mathrm{g}$ decreased to $4 \times 10^{3} \mathrm{CFU} / \mathrm{g}$ in response to Cd stress, at Cd treatment concentration of $100 \mu \mathrm{g} \mathrm{g}^{-1}$.

Table 2. pH of the vertisol treated with $\mathrm{Cd}$ and amended with Prosopis charcoal and Coirpith $(\mathrm{g} / 10 \mathrm{~kg})$

\begin{tabular}{|c|c|c|c|c|c|c|c|c|}
\hline \multirow{2}{*}{$\begin{array}{l}\text { Organic } \\
\text { amendments }\end{array}$} & \multicolumn{8}{|c|}{ Cd concentration $(\mu \mathrm{g} / \mathrm{g})$} \\
\hline & Control & 5 & 10 & 20 & 40 & 60 & 80 & 100 \\
\hline $\mathrm{Cd}$ & 6.98 & 6.97 & 6.96 & 6.94 & 6.94 & 6.90 & 6.90 & 6.90 \\
\hline Prosopis & 9.82 & & & & & & & \\
\hline 50 & 7.61 & 7.63 & 7.58 & 7.52 & 7.56 & 7.50 & 7.46 & 7.48 \\
\hline 125 & 7.68 & 7.66 & 7.66 & 7.63 & 7.60 & 7.58 & 7.50 & 7.48 \\
\hline 250 & 7.72 & 7.64 & 7.68 & 7.65 & 7.64 & 7.60 & 7.56 & 7.52 \\
\hline Coirpith & 6.36 & & & & & & & \\
\hline 50 & 6.90 & 6.84 & 6.88 & 6.86 & 6.80 & 6.82 & 6.80 & 6.78 \\
\hline 125 & 6.90 & 6.86 & 6.86 & 6.80 & 6.81 & 6.78 & 6.78 & 6.72 \\
\hline 250 & 6.86 & 6.82 & 6.79 & 6.76 & 6.72 & 6.70 & 6.70 & 6.70 \\
\hline
\end{tabular}

\section{Plant attributes}

Vigna radiata grown on $\mathrm{Cd}$ amended soils resulted in decreased root biomass, dry weight of stems and leaves. Root biomass decreased from $2.302 \mathrm{~g}$ in control plants to $0.082 \mathrm{~g}$ at Cd concentration of $80 \mu \mathrm{g} \mathrm{g}^{-1}$ (Figure 2). Seed germination was completely arrested at $100 \mu \mathrm{g} \mathrm{g}^{-1} \mathrm{Cd}$ treatment. The stem dry weight decreased from $4.236 \mathrm{~g}$ in control plants to $0.503 \mathrm{~g}$ at $\mathrm{Cd}$ concentration of $80 \mu \mathrm{g} \mathrm{g}^{-1}$ (Figure 3). Leaf biomass decreased from $3.287 \mathrm{~g}$ in control plants to $0.162 \mathrm{~g}$ at Cd concentration of $80 \mu \mathrm{g} \mathrm{g}^{-1}$ (Figure 4). The reduction recorded in the growth-related parameters may be due to the culmination of the toxic impact of $\mathrm{Cd}$ on the biochemical machinery of the plant. Of the major impacts recorded reduction in root and leaf biomass are of major concern, since the former is the supplier of soil nutrients and the latter, the biosynthetic machinery of the plant. In view of their interdependency, both would exert synergistic effect on the plant, thus decreasing the plant biomass, which increased with increase in Cd concentration. Cadmium accumulation was observed in roots, stems and leaves of Vigna radiata grown on $\mathrm{Cd}$ pretreated soils but accumulation was predominantly in the roots, as has been reported by number of researchers in different plant species (Gu et al., 2007, John et al., 2009, Prabha, 2010, Stritsis et al., 2012). The Cd content, showed a manifold increase with increase in $\mathrm{Cd}$ concentration of soil. Cadmium content in roots of control plants was $34.98 \mu \mathrm{g} \mathrm{g}^{-1} \mathrm{which}^{\mathrm{c}}$ increased to $1045.36 \mu \mathrm{g} \mathrm{g}^{-1}$ at $\mathrm{Cd}$ treatment concentration of $80 \mu \mathrm{g} \mathrm{g}^{-1}$ (Figure 5). The accumulation indices in roots, which decreased with increase in $\mathrm{Cd}$ concentration, were higher than their respective Cd treatment controls (Table 3). Stem Cd content increased from $1.787 \mu \mathrm{g} \mathrm{g}^{-1}$ in control plants to $64.10 \mu \mathrm{g} \mathrm{g}^{-1}$ at Cd treatment concentration of $80 \mu \mathrm{g} \mathrm{g}-1$ (Figure 6). The accumulation indices in stems were lower than their respective Cd treatment controls (Table 4). Leaf Cd content increased from $0.990 \mu \mathrm{g} \mathrm{g}^{-1}$ in control plants to $23.59 \mu \mathrm{g} \mathrm{g}-1$ at $\mathrm{Cd}$ concentration of $80 \mu \mathrm{g} \mathrm{g}^{-1}$ (Figure 7). The accumulation indices for roots, stems and leaves did not show any specific trend in $\mathrm{Cd}$ treatments. The accumulation indices, as in stems, were higher than their respective $\mathrm{Cd}$ treatment controls (Table 5). In the control roots, the percentage of hyphal colonization, arbuscular colonization and vesicle percentage was 39.86\%, 9.761\% and 36.20\% respectively, all of which recorded a decrease on addition of Cd to soil. Hyphal, arbuscular and vesicular colonization were completely arrested at $100 \mu \mathrm{g} \mathrm{g}^{-1}$ of Cd (Figures 8-10). 
Table 3. Accumulation in roots of $\mathrm{Cd}$ in roots of the green gram grown on Cd, Prosopis charcoal, and Coirpith (g/10kg of soil) amended vertisol.

\begin{tabular}{|c|c|c|c|c|c|c|c|c|}
\hline \multirow{2}{*}{$\begin{array}{l}\text { Organic } \\
\text { amendments }\end{array}$} & \multicolumn{8}{|c|}{ Cd concentration $(\mu \mathrm{g} / \mathrm{g})$} \\
\hline & Control & 5 & 10 & 20 & 40 & 60 & 80 & 100 \\
\hline $\mathrm{Cd}$ & 56.42 & 123.22 & 86.46 & 79.68 & 67.82 & 71.18 & 63.51 & - \\
\hline \multicolumn{9}{|l|}{ Prosopis } \\
\hline 50 & 54.21 & 138.71 & 131.75 & 100.51 & 78.28 & 78.70 & 65.15 & - \\
\hline 125 & 60.62 & 141.02 & 133.04 & 97.79 & 74.89 & 59.66 & 52.42 & 58.50 \\
\hline 250 & 41.74 & 138.32 & 166.65 & 101.96 & 84.10 & 56.49 & 49.72 & 52.82 \\
\hline \multicolumn{9}{|l|}{ Coirpith } \\
\hline 50 & 48.37 & 119.06 & 98.87 & 95.79 & 67.27 & 72.16 & 49.98 & - \\
\hline 125 & 48.31 & 148.84 & 100.58 & 95.63 & 65.61 & 66.20 & 43.37 & - \\
\hline 250 & 43.84 & 164.84 & 95.31 & 102.84 & 65.10 & 70.17 & 40.69 & - \\
\hline
\end{tabular}

Table 4. Accumulation indices of $\mathrm{Cd}$ in the stem of green gram grown on Cd, Prosopis charcoal and Coirpith

\begin{tabular}{lllllllll}
\hline $\begin{array}{l}\text { Organic } \\
\text { amendments }\end{array}$ & \multicolumn{7}{c}{ Cd concentration $(\mu \mathrm{g} / \mathrm{g})$} \\
\cline { 2 - 9 } Cd & Control & 5 & 10 & 20 & 40 & 60 & 80 & 100 \\
Prosopis & 0.051 & 0.098 & 0.101 & 0.080 & 0.074 & 0.058 & 0.061 & - \\
50 & & & & & & & & \\
125 & 0.045 & 0.080 & 0.087 & 0.076 & 0.067 & 0.058 & 0.048 & - \\
250 & 0.039 & 0.082 & 0.089 & 0.068 & 0.078 & 0.072 & 0.058 & 0.054 \\
Coirpith & 0.040 & 0.074 & 0.073 & 0.072 & 0.073 & 0.078 & 0.058 & 0.059 \\
50 & & & & & & & & \\
125 & 0.053 & 0.092 & 0.089 & 0.072 & 0.069 & 0.061 & 0.057 & - \\
250 & 0.052 & 0.087 & 0.088 & 0.077 & 0.074 & 0.063 & 0.068 & - \\
\hline
\end{tabular}

Table 5. Accumulation indices of $\mathrm{Cd}$ in leaves of green gram grown on $\mathrm{Cd}$ and Prosopis charcoal, and Coirpith

\begin{tabular}{lllllllll}
\hline $\begin{array}{l}\text { Organic } \\
\text { amendments }\end{array}$ & \multicolumn{2}{l}{ Cd concentration $(\mu \mathrm{g} / \mathrm{g})$} & & & & & \\
\cline { 2 - 8 } & Control & 5 & 10 & 20 & 40 & 60 & 80 & 100 \\
\hline $\begin{array}{l}\text { Prosopis } \\
50\end{array}$ & 0.554 & 0.453 & 0.430 & 0.387 & 0.445 & 0.426 & 0.368 & - \\
125 & & & & & & & & \\
250 & 0.621 & 0.565 & 0.470 & 0.388 & 0.480 & 0.471 & 0.424 & 0.421 \\
Coirpith & 0.641 & 0.525 & 0.468 & 0.418 & 0.450 & 0.485 & 0.430 & 0.403 \\
50 & 0.701 & 0.548 & 0.500 & 0.451 & 0.446 & 0.449 & 0.432 & 0.377 \\
125 & & & & & & & & \\
250 & 0.618 & 0.502 & 0.472 & 0.383 & 0.444 & 0.444 & 0.444 & 0.437 \\
\hline
\end{tabular}

* Mean concentration in leaves/ mean stems metal concentration

\section{Effects of organic amendments to soil}

The application of organic amendments to soil - Prosopis charcoal and coir pith (50,125, $250 \mathrm{~g} / 10 \mathrm{Kg}$ of soil) reduced the bioavailable $\mathrm{Cd}$ in the soil, the magnitude of reduction being higher for Prosopis charcoal followed by Coir pith which was $40 \%$ and 33\% respectively. The bioavailable concentration of a metal generally depends on the strength of retention factors, strength of removal factors and the quantity of metal the soil receives at that period of time. In the present study, Cd input was greater than the immobilizing power of the soil, and the rate at which it is removed by removal factors, hence the higher availability of Cd in the soil. The observed increase in the DTPA extractable Cd with an increase in Cd addition is a further proof of the capacity limit of the immobilizing power of the soil. Amendment of soil with Prosopis charcoal increased the soil pH from 6.90 to 7.52, whereas, Coir pith addition decreased the soil pH from 6.90 to 6.72 (Table 2). The increase in soil pH by Prosopis charcoal is considered efficient as it favours decreased Cd phytoavailability in the soil. Similar results have been reported by Zhang et al., (2006) where soil pH was increased by addition of manures to the soil. The DTPA extractable Cd, therefore, was greater in Coir pith amended soil followed by Prosopis charcoal. The plant uptake of Cd seems to be influenced by the DTPA extractable Cd level in the soil, therefore, the Cd content of Vigna radiata raised on Coir pith amended soil was higher followed by Prosopis charcoal. 


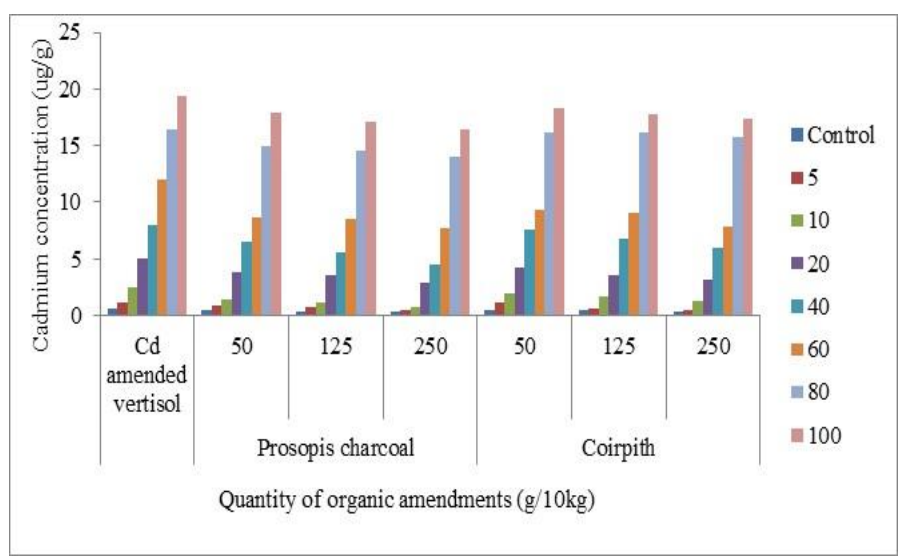

Figure 1. Cadmium content of vertisol treated with $\mathrm{Cd}$, Prosopis charcoal and Coir pith

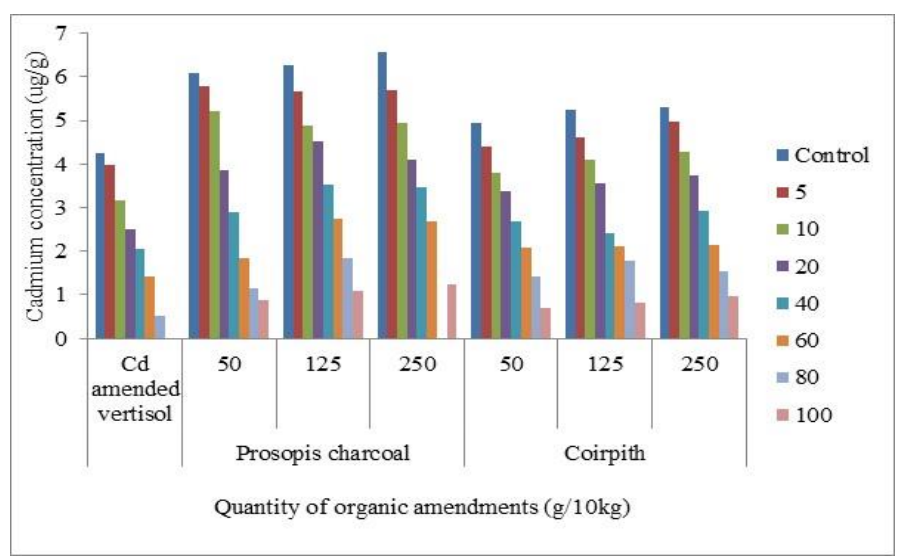

Figure 3. Stem biomass of green gram grown on Cd, Prosopis charcoal and Coirpith

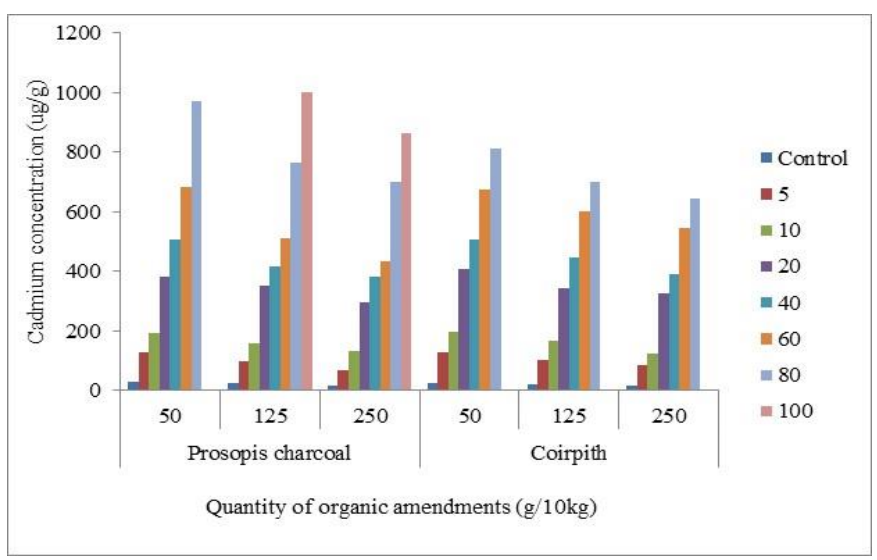

Figure 5. Cadmium content of roots of green gram grown on vertisol treated with $\mathrm{Cd}$, prosopis charcoal and Coir pith

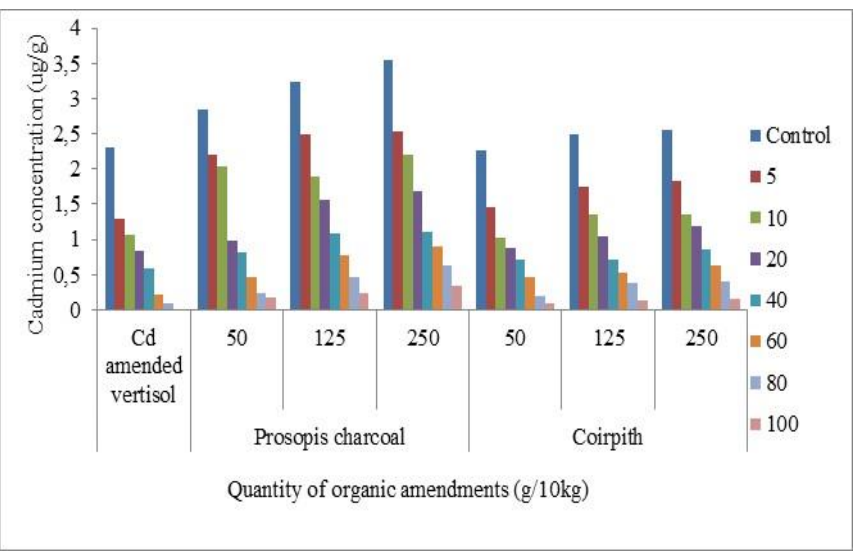

Figure 2. Root biomass of green gram grown on Cd, Prosopis charcoal Coirpith

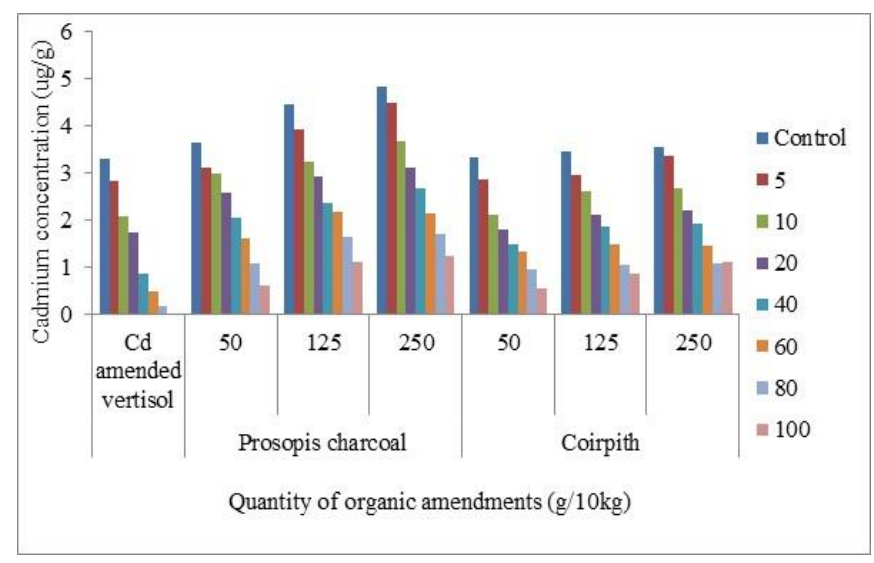

Figure 4. Leaf biomass of green gram grown on Cd, Prosopis charcoal and Coirpith

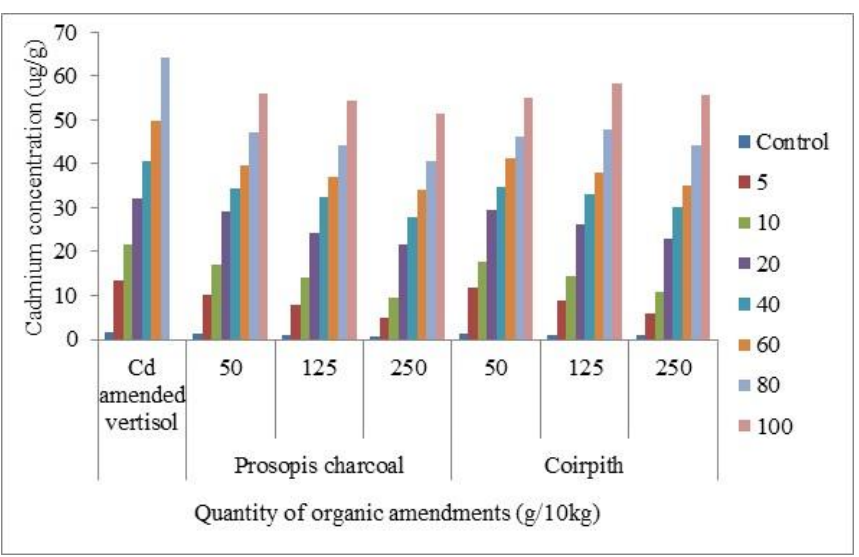

Figure 6. Cadmium content of the stem of green gram grown on Cd, Prosopis charcoal, and Coirpith

Addition of increasing quantity of organic amendments increased the total bacterial population and Vesicular Arbuscular Mycorrhiza (VAM) in the soil (Fig 11and 13). With Prosopis charcoal (125 and $250 \mathrm{~g} /$ $10 \mathrm{Kg}$ ), considerable percentage of hyphae, arbuscule and vesicle was observed in the roots even in the highest treatment concentration of $\mathrm{Cd}$ of $100 \mu \mathrm{g} \mathrm{g}{ }^{-1}$ (Figures 8-10). The increase recorded at the highest amendment concentration of Prosopis charcoal and Coir pith was $27 \%$ and 19\% in the control soil and in the Cd pretreated soil it ranged from 45 to $125 \%$ and 27 to $50 \%$ compared to treatment controls (Figures 810). The increase recorded at the highest amendment concentration of Prosopis charcoal and Coir pith was $11 \%$ and 5\% in the control soil and in the Cd pretreated soil it ranged from 27 to $60 \%$ and 19 to $50 \%$ compared to treatment controls respectively (Figures 8-10). In all the above cases it was observed that the remediative effect was higher for Prosopis charcoal followed by coir pith. Microbial population depends on 
the availability of organic carbon for its growth and activity, and organic carbon in view of its CEC and high surface area facilitate adsorptive reduction of bioavailable $\mathrm{Cd}$. Both of which would naturally enhance the biological activity as is seen from the revival of bacterial population and activity in the organic materials amended soil. Perusal of the results showed that though organic amendments revived biological activity, they have not completely restored the activity to its original level, since all the organic materials at the amendment concentration used have not altogether removed the bioavailable $\mathrm{Cd}$, but only reduced it. The reason being that no organic material used, even at the highest concentration, had the potential to remove $100 \%$ of the available Cd irrespective of the range of concentration of Cd tested (5 to $100 \mu \mathrm{g} \mathrm{g}^{-1}$ of soil) and with increasing $\mathrm{Cd}$ concentration, the percentage removal of $\mathrm{Cd}$ decreased.

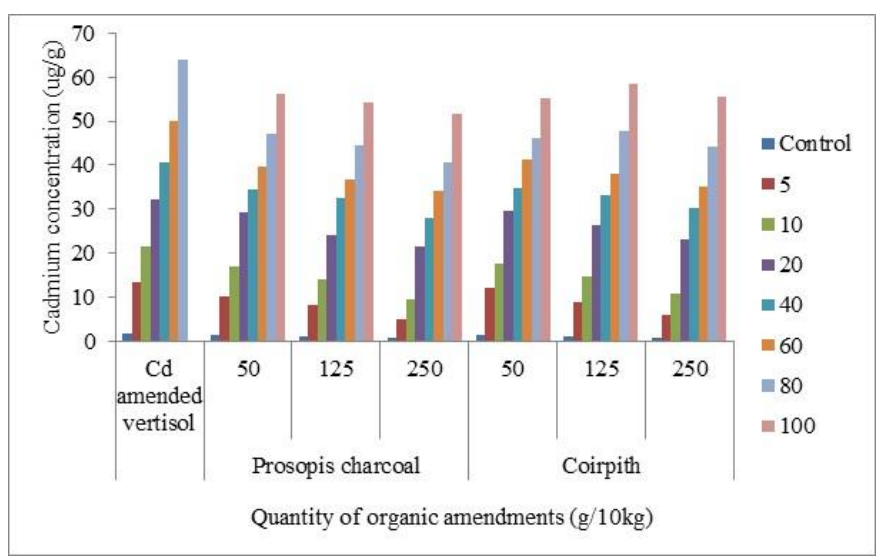

Figure 7. Cadmium content of leaves of green gram grown on Cd and Prosopis charcoal and Coirpith

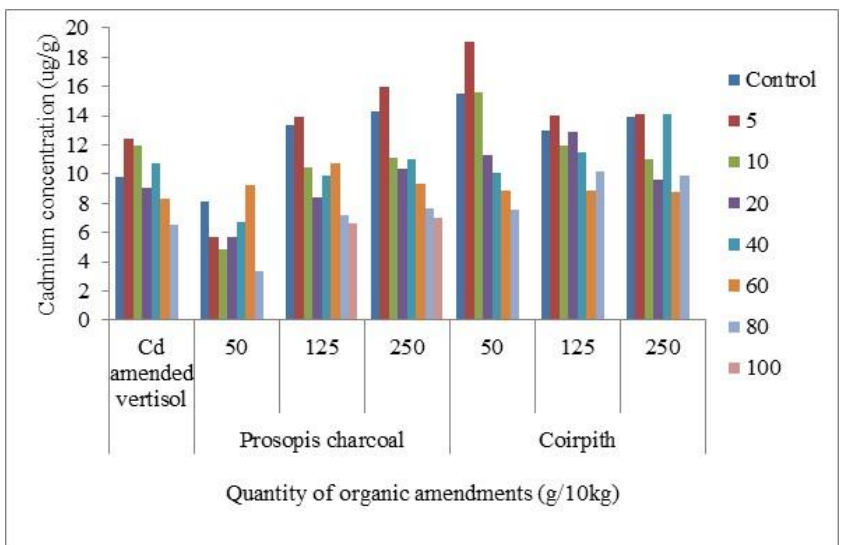

Figure 9. Arbuscule colonization of roots treated with Cd, Prosopis charcoal, and Coirpith

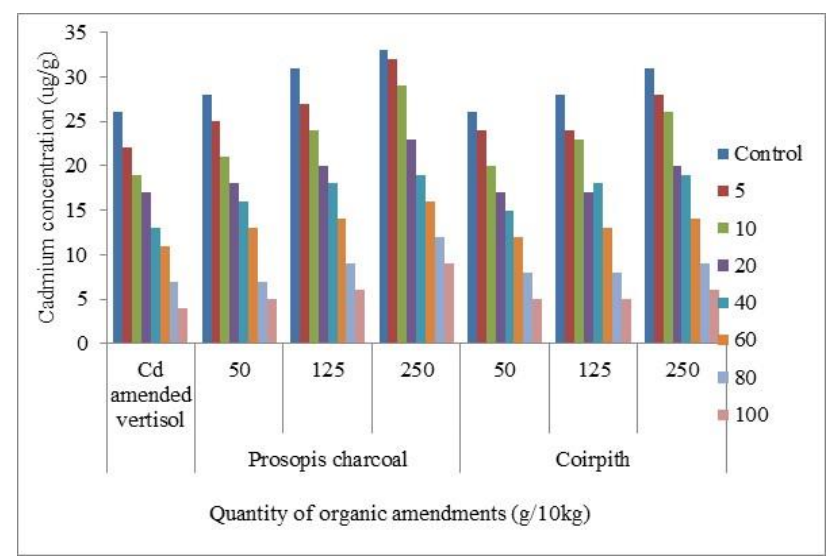

Figure 11. Total bacterial population of vertisol treated with Cd, Prosopis charcoal and Coir pith

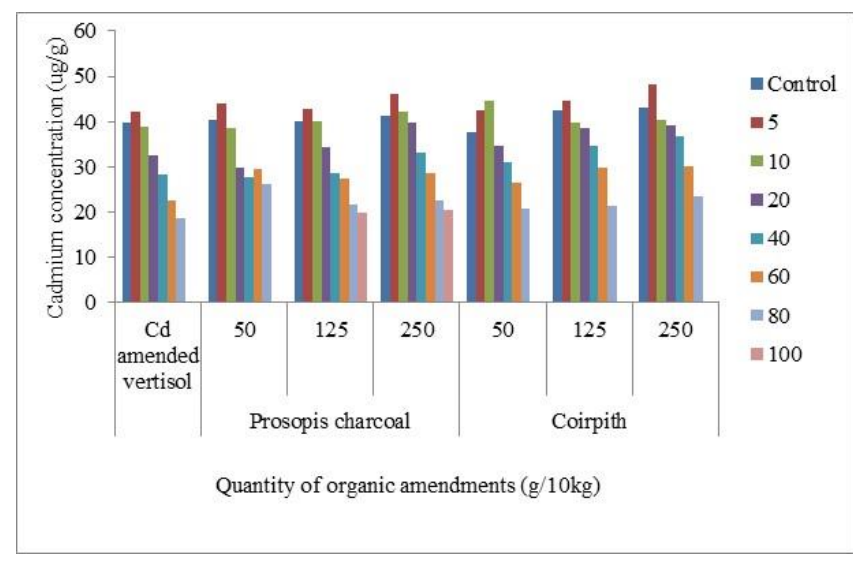

Figure 8. Hyphal colonization of roots treated with $\mathrm{Cd}$, Prosopis charcoal, and Coirpith

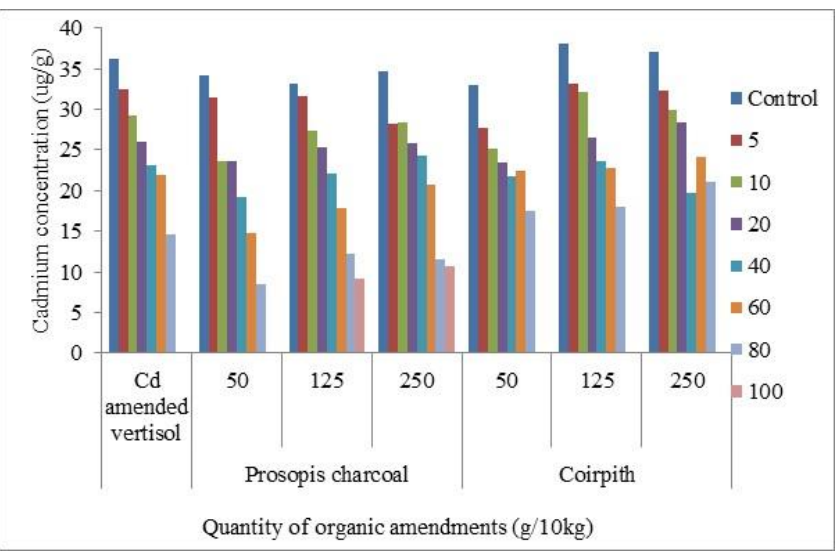

Figure 10. Vesicle colonization of roots treated with $\mathrm{Cd}$, Prosopis charcoal and Coirpith

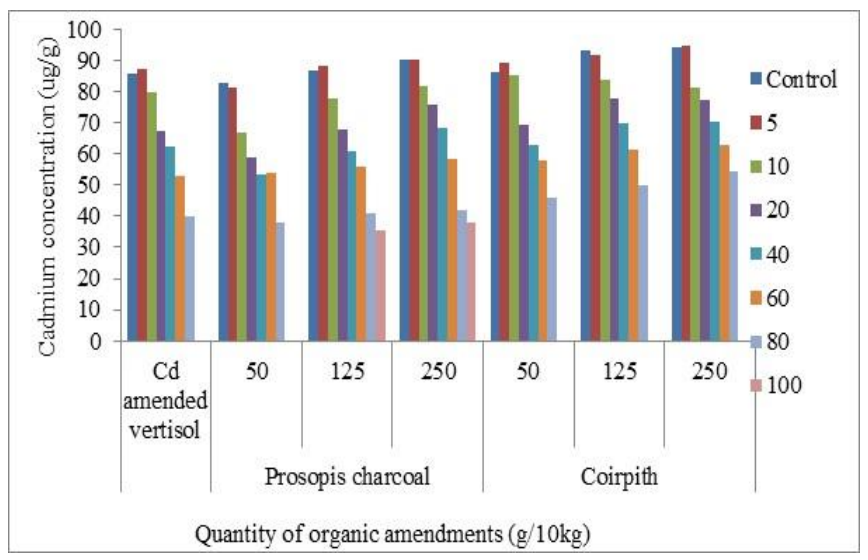

Figure 12. Total mycorrhizal colonization of roots treated with Cd, Prosopis charcoal and Coirpith 


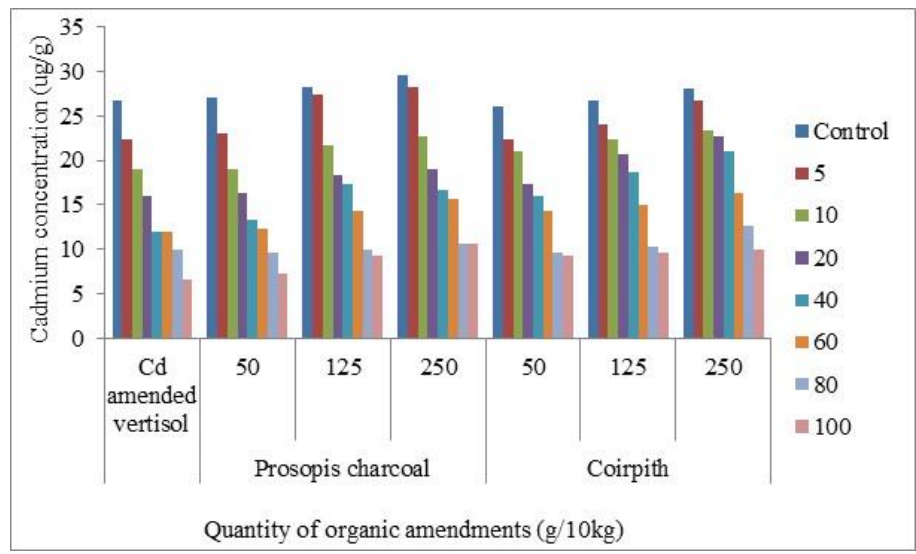

Figure 13. VAM fungal spore number in vertisol treated with Cd, Prosopis charcoal and Coir pith

\section{Effect of organic amendments on growth of plants}

Addition of Prosopis charcoal and Coir pith to Cd pretreated soils increased the root biomass from $0.082 \mathrm{~g}$ at $80 \mu \mathrm{g} \mathrm{g}^{-1} \mathrm{Cd}$ treatment to $0.532 \mathrm{~g}$ on addition of $250 \mathrm{~g}$ of Prosopis charcoal, and to $0.394 \mathrm{~g}$ on addition of 250 $\mathrm{g}$ of Coir pith (Figure 2). Similarly, an overall increase was recorded in the biomass of the above ground parts compared to that recorded in the Cd pretreated soil (Figures 3,4). The observed increase in root biomass, therefore the increased absorptive surface would have contributed for the increased uptake of nutrients, which can be evidenced by the increase in plant biomass. Comparatively the increase was greater in leaves followed by stems. Also, Seed germination occurred in response to Prosopis charcoal, seedlings established and considerable amount of root biomass was also produced at $100 \mu \mathrm{g} \mathrm{g}{ }^{-1} \mathrm{Cd}$ treatment concentration. Addition of organic amendments have been reported to stimulate soil microbes and their activities (Frankenberger and Bingham, 1982; Mora et al., 2005). Research has shown that organic amendments are effective in the reduction of bioavailable Cd by altering its speciation. Segregation of Cd to different fractions upon organic amendments depends on the chemical composition and $\mathrm{pH}$ of the organic materials used (Narwal and Singh, 1998, Shuman, 1998). When Prosopis charcoal and coir pith were added to the soils, the magnitude of decrease of biomass was progressively less with increasing treatment concentration of Prosopis charcoal and coir pith, the protective effect being higher in Prosopis charcoal than in Coir pith. The increase recorded in the bacterial population in organic materials amended soils in the presence of Cd in the present study corroborates with the earlier findings.

Addition of organic amendments, however, did not significantly decrease the Cd content in plant parts (roots, stems and leaves). Though Cd accumulation level decreased, it was higher than in the control plants. Among the organic materials, Prosopis charcoal was more efficient in reducing the Cd uptake by Vigna radiata and thereby its accumulation in leaves and stems. In roots, both Prosopis charcoal and coir pith were equally effective in reducing Cd content (Figures 5-7).

What is more important in the remediation of $\mathrm{Cd}$ contaminated soil using organic amendment is the level of success achieved in the reduction of soluble and exchangeable $\mathrm{Cd}$ and to which fraction it is translocated and the length of period the organic material remains stable in the soil environment. Coirpith is resistant to microbial degradation but not totally unbiodegradable. Composting of Coirpith has been achieved using urea and Pleuroetus species. Prosopis charcoal is the most resistant, and would remain in the soil intact for centuries, therefore, release of $\mathrm{Cd}$ from it depends more on the nature of $\mathrm{Cd}$ adsorption rather than by degradation. Hence, Prosopis charcoal is considered as the best among the organic amendments used in the study for stabilization of $\mathrm{Cd}$ in the soil for longer duration. Further, it is more economical in terms of its production and use. Such a remediation technique with no direct involvement of any live plant species would be termed more appropriately as biochemoimmobilization or biochemostabilization technique encompassing all chemical and biological materials used as stabilizers of heavy metals in the soil.

\section{Conclusion}

The present study showed that the increased availability of $\mathrm{Cd}$ in the soil for longer duration can be managed by employing adsorptive surfaces such as organic carbon amendments, the choice of which depends on their potential to redistribute the soil $\mathrm{Cd}$ more in unavailable fractions. The use of organic amendments caused 
revival of biological activity, favored the growth of Vigna radiata, and resulted in a decrease in the Cd content of Vigna radiata. Among the organic amendments used in this study, Prosopis charcoal was more effective in reducing the DTPA extractable $\mathrm{Cd}$ in the soil and the Cd content of roots, stem and leaves, and resulting in an increase in the root, leaf and stem biomass. Coirpith was more effective in increasing the total mycorrhizal colonization of roots and second best in reducing the soil, root, stem and leaf Cd levels.

\section{Acknowledgements}

The author P. Senthilkumar is highly thankful to the Council of Scientific and Industrial Research (CSIR), New Delhi and Bharathiar University, Coimbatore for their financial assistance in the form of Senior Research fellowship and University Research fellowship for this research.

\section{References}

Adhikari, T., Singh, M.V., 2003. Sorption of lead and cadmium in some soils of India. Geoderma 114: 81-92.

Alder, H.L., Roessler, E.B., 1977. The analysis of variance. In Introduction to probability and statistics, $6^{\text {th }}$ edition. W.H. Freeman and Company, San Francisco, USA. pp. 318-354

Bailey, S.E., Olin, T.J., Bricka, R.M., Adrian, D.D., 1999. A review of potentially low cost sorbents for heavy metals. Water Research 33: 2469-2479.

Bolan, N. S., Adriano, D. C., Mahimairaja, S., 2004. Distribution and bioavailability of trace elements in livestock and poultry manure by products. Critical Reviews in Environmental Science and Technology 34: 291-338.

de Mora, A. P., Ortega-Calvo, J.J., Cabrera, F., Madejo, E., 2005. Changes in enzyme activities and microbial biomass after "in situ" remediation of a heavy metal-contaminated soil. Applied Soil Ecology 28: 125-137.

Frankenberger, W.T., Jr., Bingham, F.T., 1982. Influence of salinity on soil enzyme activities. Soil Science Society of America Journal 46: 1173-1177.

Galstyan, A. Sh., 1970. A method of determining the activity of hydrolytic enzymes in soil. Soviet Soil Science 2: 170-175.

Garcla-Sanchez., A Alastuey, A., Querol., X., 1999. Heavy metal adsoption by different minerals: application to the remediation of polluted soils. Science of the Total Environment 242: 179-188.

Gu,J., Qi, L., Jiang, W., Liu,D., 2007. Cadmium accumulation and its effects on growth and gas exchange in four populous cultivars. Acta Biologica Cracoviensia Series Botanica 49(2): 7-14.

Gworek, B., 1992. Inactivation of cadmium in contaminated soils using synthetic zeolites. Environmental Pollution 75: 269-271.

Haidouti, C., 1997. Inactivation of mercury in contaminated soils using natural zeolites. Science of the Total Environment 208: 105-109.

Herwijnen, R., Hutchings, T. R., Al-Tabbaa, A., Moffat, A. J, Johns, M. L., Ouki, S. K., 2007. Remediation of metal contaminated soil with mineral-amended composts. Environmental Pollution 150: 347-354.

Jha, D.K., Sharma,G. D., Mishra,R.R., 1992. Soil microbial population numbers and enzyme activities in relation to altitude and forest degradation. Soil Biology and Biochemistry 24: 761-767.

John, R., Ahmad, P., Gadgil, K., Sharma,S., 2009. Heavy metal toxicity; effect on plant growth , biochemical parameters and metal accumulation by Brassica juncea L. International Journal of Plant Production 3(3): 65-76.

Kalmykova,Y., Strmvall, A., Steenari, B., 2008. Adsorption of $\mathrm{Cd}, \mathrm{Cu}, \mathrm{Ni}, \mathrm{Pb}$ and $\mathrm{Zn}$ on Sphagnum peat from solutions with low metal concentrations. Journal of Hazardous Materials 152: 885-891.

Kelly, W.D., Kabana, R.R., 1974. Effects of potassium azide on soil microbial populations and soil enzymatic activities. Canadian Journal of Microbiology 21: 565-570.

Kumpiene, J., Lagerkvist, A., Maurice, C., 2008. Stabilization of $\mathrm{As}, \mathrm{Cr}, \mathrm{Cu}, \mathrm{Pb}$ and $\mathrm{Zn}$ in soil using amendments-A review. Waste Management 28: 215-225.

Ladd, J. N., Butler, J.H. A., 1972. Short-term assays of soil proteolytic enzyme activities using proteins and dipeptide derivatives as substrates. Soil Biology and Biochemistry 4: 19-30.

Li, T.Q., Di, Z.Z., Yang, X.E., Sparks, D.L., 2011. Effects of dissolved organic matter from the rhizosphere of the hyperaccumulator Sedum alfredii on sorption of zinc and cadmium by different soils. Journal of Hazardous Materials 192: 1616-1622.

Lindsay, W.L., Norvell,W.A., 1978. Development of a DTPA soil test for zinc, iron, manganese and copper. Soil Science Society of America Journal 42: 421-428.

Liu, A., Gonzalez, R. D., 1999. Adsorption/desorption in a system consisting of humic acid, heavy metals and clay minerals. Journal of Colloid and Interface Science 218: 225-232.

Liu, P., 2007. Polymer modified clay minerals: a review. Applied Clay Science 38: 64-76.

Mench, M., Lepp, N., Bert, V., Schwitzguebel, J-P., Gawronski, S. W., Schoder, P., Vangronsveld, J... 2010. Successess and limitations of phytotechnologies at field scale: outcomes, assessment and outlook from COST action 859. Journal of Soils and Sediments 10: 1039 - 1070. 
Mercier, L., Detellier, C., 1995. Preparation, characterization and applications as heavy metals sorbents of covalent grafted thiol functionalities on the interlamellar surface of montmorillonite. Environmental Science and Technology 29: 1318-1323.

Mhatre, G. N., Pankhurst, C. E., 1997 Bioindicators to detect contamination of soils with special reference to heavy metals. In: Pankhrust C E, Doube, B M, Gupta, V V S R (Eds). Biological indicators of soil health and sustainable productivity. CAB International. New York. Pp. 349 - 369.

Missana, T., Gutierrez, M. G., Alonso, U., 2008. Sorption of strontium onto illite/smectite mixed clays. Physics and Chemistry of the Earth 33 (S): 156-162

Muthukumar, T., Udaiyan, K., Manian, S., 1996. Vesicular-arbuscular mycorrhizae in tropical sedges of Southern India. Biology and Fertility of Soils 22: 96-100.

Narwal, R.P., Singh, B. R., 1998. Effect of organic materials on partitioning, extractability and plant uptake of metals in alum shale soil. Water Air and Soil Pollution 103: 405-421.

Nissen, R., Lepp, N. W., Edwards, R., 2000. Synthetic zeolites as amendments for sewage sludge - based compost. Chemosphere 41: 263-269.

Piper, C. S., 1966. Soil and plant analysis. Hans Publishers, Bombay.

Prabha, D., 2010. Responses of selected microorganisms, plant and earthworm to cadmium and selenium exposure. 2010. Ph.D. Thesis. Department of Environmental Sciences, Bharathiar University.

Roy, M., McDonald, L. M., 2014. Metal uptake in plants and health risk assessments in metal-contaminated smelter soils, Land Degradation \& Development doi:10.1002/ldr.2237, in press.

Sanita di Toppi, L., Gabbrielli, R., 1999. Response to cadmium in higher plants. Environmental and Experimental Botany 41: $105-130$.

Sauve, S., Turmel, S.M., Roy, A.G., Courchesne, F., 2003. Solid solution partitioning of $\mathrm{Cd}, \mathrm{Cu}, \mathrm{Ni}, \mathrm{Pb}$ and $\mathrm{Zn}$ in the organic horizons of a forest soil. Environmental Science and Technology 37: 5191-5196.

Shuman, L. M., 1998. Effect of organic waste amendments on cadmium and load in soil fractions of two soils. Communications in Soil Science and Plant Analysis 29: 2939 - 2952.

Sisa, R., 1993. Enzymova aktivita pudy jako ukazatel jeji biologicke activity. Rostl. Vyr, 39, 817-825

Sposito, G., Lund, L. J., and Chang, A. C., 1982. Trace metal chemistry in arid-zone field soils amended with sewage sludges: I. Fractionation of $\mathrm{Ni}, \mathrm{Cu}, \mathrm{Zn}, \mathrm{Ca}$ and $\mathrm{Pb}$ in solid phases. Soil Science Society of America Journal 46: 260264.

Stritsis, C., Steingrobe, B., Claassen, N., 2012. Shoot cadmium concentration of soil-grown plants as related to their root properties. Journal of Plant Nutrition and Soil Science 175: 456-465.

Vacca, A., Bianco, M. R., Murolo, M., Violante, P., 2012. Heavy metals in contaminated soils of the Rio Sitzerri floodplain (Sardinia, Italy): Characterization and impact on pedodiversity, Land Degradation and Development 23: 250-364.

Walker, D.J., Clemente, R., Bernal, M.P., 2004. Contrasting effects of manure and compost on soil pH, heavy metal availability and growth of Chenopodium album L. in a soil contaminated by pyritic mine waste. Chemosphere 57: 215-224.

Walker, D.J., Clemente,R., Roig,A., Bernal, M.P., 2003. The effects of soil amendments on heavy metal bioavailability in two contaminated Mediterranean soils. Environmental Pollution 122: 303-312.

Wu, P.X., Wu,W.M., Li, S.Z., Xing, N., Zhu, N.W., Li,P.,Wu,J.H., Yang,C., Dang,Z., 2009. Removal of Cd2+ from aqueous solution by adsorption using Fe-montmorillonite. Journal of Hazardous Materials 169: 824-830.

Yang, D., Zeng, D. H., Li, L. J., Mao, R., 2012. Chemical and microbial properties in contaminated soils around a magnesite mine in Northeast China. Land Degradation and Development 23: 256-262.

Zantua, M. T., Bremner, J.M., 1976. Production and persistance of urease activity in soil. Soil Biology and Biochemistry 8: 369-374.

Zhang, Q., Li,J.M., Xu, M.G., Song, Z.G., Zhou,S.W., 2006. Effects of amendments on bioavailability of cadmium and zinc in compound contaminated red soil. Journal of Agro-Environment Science 25: 861-865.

Zorpas, A.A., Constantinides, T., Vlysside,s A.G., Haralambous, I., Loizidou, M., 2000. Heavy metal uptake by natural zeolite and metals partitioning in sewage sludge compost. Bioresource Technolgy 72: 113-119. 